\title{
Factors Affecting the Adoption of Paddy Varieties in Kapurthala District of Punjab, India
}

\author{
Jatinder Manan, Manoj Sharma* and Manpreet Jaidka \\ PAU's Krishi Vigyan Kendra, Kapurthala 144620 (Punjab), India \\ *Corresponding author
}

\begin{tabular}{|l|}
\hline Ke y w o r d s \\
Activities, Adoption, \\
$\begin{array}{l}\text { Cost of seed, } \\
\text { Extension, Factors, } \\
\text { Paddy, Variety }\end{array}$ \\
\hline Article Info \\
\hline $\begin{array}{l}\text { Accepted: } \\
\text { 120 August } 2018 \\
\text { Available Online: } \\
\text { 10 September } 2018\end{array}$ \\
\hline
\end{tabular}

\section{A B S T R A C T}

The district Kapurthala is a fully diversified in cultivation of crops as the major cropping sequence followed is paddy-wheat, paddy-potato-muskmelon/watermelon/spring maize/ vegetables. The area under two crops namely sunflower and summer moong is uncertain and depends on the selling rate prevalent in the market at the time of harvesting and ease of marketing. This study was based on a survey conducted on 100 farmers in the district. A questionnaire was developed and information was collected through interview method in the grain markets at Kapurthala and Sultanpur blocks during October, 2017. It was noticed that the highest grain yield obtained was in Pusa 44 (76.5 q/ha) followed by PR 121 (74 $\mathrm{q} / \mathrm{ha}$ ) and PR 126 (71.0 q/ha). Likewise, data regarding gross returns (Rs/ha) followed the similar trend. This indicates that those farmers who are following paddy-wheat crop rotation, preferred to grow Pusa 44 and PR 121 (both long duration varieties) compared to PR 126 (short duration variety). Farmers select these varieties keeping in view the gross returns obtained which were found to be highest for Pusa 44. This was contrary to the recommendation of the scientists who advocate that productivity of grains on per day basis was highest in PR $126(57.7 \mathrm{~kg} / \mathrm{ha} / \mathrm{d})$ compared to PR $121(51.8 \mathrm{~kg} / \mathrm{ha} / \mathrm{d})$ and Pusa 44 (49.0 $\mathrm{kg} / \mathrm{ha} / \mathrm{d})$. Further, the study revealed that 59 per cent farmers were interested to grow potato and pea crops whereas, 11 per cent preferred vegetable crops paddy variety PR 126 , whereas 30 per cent farmers were interested to grow wheat after paddy harvesting. In paddy-wheat crop ration PR 121 and Pusa 44 are first preference of farmers because of higher productivity and good net returns. Varietal characteristics, seed source and its cost, extension activities, package of practices of a variety and marketing are some of the important factors in adoption of a newly released variety in a particular area.

\section{Introduction}

Rice and wheat are the major crops cultivated by the farmers of Punjab. Rice followed by wheat is the main cropping system in the state.

More than 60 per cent of the total cultivated area in the state in the kharif season is occupied by rice. Other rice based cropping systems prevalent in the state are: Rice-fallow; Rice-Berseem/ Linseed/ Gram/ Barley; Rice/ Basmati Rice-Wheat-/Summer Moong/Green maturing; Rice-Celery; Rice-Potato/PeasCelery; Rice-Potato-Potato/ Summer Moong/ Sunflower/ Celery/ Wheat/ Cucurbits; RiceToria-sunflower; Basmati rice-Mentha; Bamati rice-Berseem (seed); Basmati riceBerseem (fodder). 
During the kharif season, paddy is the major crop sown in about 1.18 lakh ha (2017-18) area in the district Kapurthala. It has been observed that there is a great curiosity among the farming community to sow newly released varieties of crops and when any recommendation is made by the state agricultural university. On the other hand, every year farmers expect another new variety. Singh et al., (2015) reported that about 50 per cent of farmers prefer to cultivate more than one variety of paddy which include basmati varieties and area covered by such farmers was 342.2 ha $(36.4 \%$ of total area surveyed). Out of the total area under basmati rice, 113.2 ha was under Pusa Basmati 1121(12.04\%) and 229 ha under Pusa Punjab Basmati 1509 (24.36\%). Amongst nonbasmati varieties of rice, variety PR 121 was the most popular and occupied $16.43 \%$ area followed by variety HKR 47 (10.64\%) and Pusa 44 (8.98\%). Paddy variety PR 121 gave highest yield of $75.8 \mathrm{q} / \mathrm{ha}$ and also resulted in highest gross returns (Rs 1, 04,217/ha) during kharif 2014-15. During the year 2016, the Punjab Agricultural University released a new paddy variety PR126 which is an early maturing rice variety. Its average plant height is $102 \mathrm{~cm}$ and matures in about 123 days after seeding it. Its' average paddy yield is 75.0 quintals per ha.

The district Kapurthala is a fully diversified in cultivation of crops as the major cropping sequence followed is paddy-wheat, paddypotato-muskmelon/watermelon/spring maize/ vegetables. The area under two crops namely sunflower and summer moong is uncertain and depends on the selling rate prevalent in the market at the time of harvesting and ease of marketing. It is worth to mention that three crops sequence is followed on approximately 15,000 ha area and therefore, farmers prefer to grow short duration varieties. Hence, an effort was made to study the factors affecting the adoption of paddy varieties in the district
Kapurthala and shift in the area under paddy varieties being grown by the farmers during kharif 2017-18.

\section{Materials and Methods}

This study was based on a survey conducted on 100 farmers in the district. A questionnaire was developed and information was collected through interview method in the grain markets at Kapurthala and Sultanpur blocks, during October, 2017. The various parameters noted were name and address of the farmer, area sown, variety, average yield obtained, next crop to be sown, area to be sown and reasons of growing a particular variety and crop. The data were tabulated and classified into different categories.

\section{Results and Discussion}

\section{Area under different paddy varieties}

The data (Table 1) showed that 36 per cent farmers preferred to grow paddy variety PR 126 and PR 121 (44 \%) followed by Pusa 44 (12\%), HKR $47(4 \%)$ and Pusa Basmati $1121(3 \%)$, however, the maximum area was put under PR 126 (54.5\%) followed by PR 121 (29.5\%), HKR 47 (7.9\%), Pusa 44 (7.7\%), Pusa Basmati 1121(0.3\%) and Diksha (0.1\%).

Paddy variety PR 126 is an early maturing rice variety which took about $123 \mathrm{~d}$ after seeding an possesses long slender, clear translucent grains and average yield is about $75 \mathrm{q} / \mathrm{ha}$. On the other hand, paddy variety PR 121 matures in $140 \mathrm{~d}$ after seeding; its plant height is 98 $\mathrm{cm}$. Its grains are long slender, translucent with good cooking quality and the average yield is about $76.25 \mathrm{q} / \mathrm{ha}$.

Hence, the trend showed that farmers preferred to grow short duration varieties compared to long duration in order to grow three crops in a year. 


\section{Yield obtained by different paddy varieties}

It was noticed that the highest grain yield obtained was in Pusa 44 (76.5 q/ha) followed by PR 121 (74 q/ha) and PR 126 (71.0 q/ha). Likewise, data regarding gross returns (Rs/ha) followed the similar trend (Table 2). This indicates that those farmers who are following paddy-wheat crop rotation, preferred to grow Pusa 44 and PR 121 (both long duration varieties) compared to PR 126 (short duration variety). Farmers select these varieties keeping in view the gross returns obtained which were found to be highest for Pusa 44. This was contrary to the recommendation of the scientists who advocate that productivity of grains on per day basis was highest in PR 126 $(57.7 \mathrm{~kg} / \mathrm{ha} / \mathrm{d})$ compared to PR $121(51.8$ $\mathrm{kg} / \mathrm{ha} / \mathrm{d})$ and Pusa 44 (49.0 kg/ha/d).

Therefore, it can be said that all the extension agencies involved in transfer of technology need to be motivated and educated for dissemination of such scientific findings among the farmers of the area. Furthermore, the long duration varieties of the paddy remain in the field for a longer period and thus require more quantity of water as well as all nutrients, which will make the cropping sequence unsustainable in a long run.

This situation has resulted in the increased cost of production because in order to get the maximum yield per unit area, farmers used more quantity of chemical fertilizers and pesticides than the recommendations (Singh $e t$ al., 2015).

\section{Cropping sequence followed in the district}

The study revealed that 59 per cent farmers were interested to grow potato and pea whereas, 11 per cent preferred vegetable crops paddy variety PR 126 , whereas 30 per cent farmers were interested to grow wheat after paddy harvesting (Table 3). These values cleared the preference of short duration variety (PR 126) on 524 acres area during the year 2017-18 in the district Kaputhala.

In case of paddy variety PR 121 were sowing wheat $(86 \%)$ and potato (12\%) for next crop. Thus, it was evident that there was a great demand of short duration variety by majority of farmers who are practicing three crops rotations like paddy-potato-wheat or paddypeas-wheat and long duration variety (PR 121 and Pusa 44), where preferred in paddy-wheat cropping sequence. This finding was further supported by the fact that those farmers who grew Pusa 44 variety (long duration) of paddy preferred wheat crop in the sequence because Pusa 44 took about $155 \mathrm{~d}$ from seeding to maturity and under such situation, it is not possible to go for either potato, peas or carrots etc.,

\section{Shift in area under paddy varieties}

In order to evaluate the likely satisfaction level of farmers about the performance of different paddy varieties grown by them, the data revealed that there was a major shift from PR 126 to PR 121, 55.5 per cent farmers were found to be satisfied whereas 44.5 per cent farmers shifted towards PR 121 stating that there was a marketing problem with PR 126 and got less selling price than the minimum support price (MSP) fixed by the government. On the other hand, no marketing problem was faced by the PR 121 growers. This fact can be explained to some extent that the paddy variety PR 126 matures by $15^{\text {th }}$ September and at that time, the moisture content in the produce was found to be about 20 to 22 per cent whereas the desired moisture level is 16 per cent by the procurement. Moreover, the government purchase starts w.e.f. first October, and during September month, the local traders are the only purchaser of PR 126 variety who might have created their monopoly in the market. 
This observation was further supported by the data (Table 4) where farmers cultivating PR 121 , only 4 per cent shifted towards PR 126 and 2 per cent towards Pusa 44. This might be due to the reason that all of them were fully satisfied with the yield level and selling rate (which was found to be highest Rs.1547.8/q). Moreover, they have to go for wheat crop after the harvesting of paddy crop and there is no urgency to get the paddy fields vacated by the middle of September or October as wheat crop is to be sown in the end of October or first week of November onwards. Regarding farmers who grew Pusa 44 shifted their interest towards PR 121 (33.3\%), PR 126 (8.3\%) and Pusa 44 (58.3\%) which clearly indicates that every time farmers are in search of newly developed variety like PR 126 or PR 121.

\section{Factors identified for selecting the paddy variety by the farmers}

It has been reported that the rice growers make use of unregistered and uncertified rice varieties whose yields are quite lower compared to the improved and certified rice varieties due to various factors such as less access to certified seeds, lack of awareness of adoption of improved rice varieties, lack of government subsidy, poor infrastructure, rising prices of fertilizers, shortage of irrigation and lack of credit facilities (Abedullah and Mushtaq, 2007; Chandio et al., 2017). Majority of farmers typically use the last year's crop seeds instead of purchasing the seeds of improved released rice varieties. Likewise, varieties characteristics play a vital role in influencing farmer's adoption behavior. If the characteristics satisfy the need and interest of the farmers they will adopt (Tadesse, 2008).

\section{Duration of the variety}

In Kapurthala, farmers prefer to go for short duration variety as they have to cultivate three crops in a year especially in two blocks namely Sultanpur Lodhi and Kapurthala. This is the main reason that the area under Basmati rice is negligible in this district. It was worth to mention that since Pusa Punjab Basmati 1509 took about $125 \mathrm{~d}$ for its maturity therefore proved as boon to the farmers of the district during the year 2014-15 as they could sow potato-sunflower, potato muskmelon, potato-maize after the harvest of this basmati variety which otherwise was not possible by growing long duration basmati varieties like Basmati 386 or 370 (Singh et al., 2015).

Table.1 Area under different paddy varieties in district Kapurthala

\begin{tabular}{|l|l|c|c|}
\hline Sr. No. & Paddy variety & Farmer preference $(\mathbf{\%})$ & Area sown (\%) \\
\hline $\mathbf{1}$ & PR 126 & 36.0 & 54.5 \\
\hline $\mathbf{2}$ & PR 121 & 44.0 & 29.5 \\
\hline $\mathbf{3}$ & HKR 47 & 4.0 & 7.9 \\
\hline $\mathbf{4}$ & Pusa 44 & 12.0 & 7.7 \\
\hline $\mathbf{5}$ & Pusa Basmati 1121 & 3.0 & 0.3 \\
\hline $\mathbf{6}$ & Diksha & 1.0 & 0.1 \\
\hline
\end{tabular}


Table.2 Yield and productivity of different paddy varieties in district Kapurthala

\begin{tabular}{|l|l|c|c|c|}
\hline $\begin{array}{l}\text { Sr. } \\
\text { No. }\end{array}$ & Paddy variety & $\begin{array}{c}\text { Grain yield } \\
(\mathbf{q} / \mathbf{h a})\end{array}$ & $\begin{array}{c}\text { Gross returns } \\
\text { (Rs/ha) }\end{array}$ & $\begin{array}{c}\text { Productivity of grains } \\
\text { kg/ha/day }\end{array}$ \\
\hline $\mathbf{1}$ & PR 126 & 71.0 & $1,03,992 /-$ & 57.7 \\
\hline $\mathbf{2}$ & PR 121 & 74.0 & $1,14,559 /-$ & 51.8 \\
\hline $\mathbf{3}$ & Pusa 44 & 76.5 & $1,17,745 /-$ & 49.0 \\
\hline $\mathbf{4}$ & HKR 47 & 68.6 & $1,04,432 /-$ & 50.8 \\
\hline $\mathbf{5}$ & Diksha & 69.5 & $1,12,375 /-$ & 48.9 \\
\hline $\mathbf{6}$ & Pusa Basmati 1121 & 32.5 & $91,000 /-$ & 23.7 \\
\hline
\end{tabular}

Table.3 Effect of paddy varieties sown on selection of succeeding crop

\begin{tabular}{|l|l|c|c|c|}
\hline $\begin{array}{l}\text { Sr. } \\
\text { No. }\end{array}$ & Paddy variety & \multicolumn{3}{|c|}{ Area sown under different succeeding crops (per cent) } \\
\hline $\mathbf{1}$ & PR 126 & Pea/Potato & Other vegetables & Wheat \\
\hline $\mathbf{2}$ & PR 121 & 12 & 11 & 30 \\
\hline $\mathbf{3}$ & Pusa 44 & 0 & 2 & 86 \\
\hline $\mathbf{4}$ & Pusa Basmati 1121 & 100 & 0 & 100 \\
\hline $\mathbf{5}$ & HKR 47 & 43 & 0 & 0 \\
\hline $\mathbf{6}$ & Diksha & 43 & 0 & 57 \\
\hline
\end{tabular}

Table.4 Expected shift in paddy varieties in district Kapurthala

\begin{tabular}{|l|l|c|c|c|c|}
\hline \multirow{2}{*}{$\begin{array}{l}\text { Sr. } \\
\text { No. }\end{array}$} & Paddy variety & \multicolumn{3}{|c|}{ Shift to other varieties in coming season (\%) } \\
\hline $\mathbf{1}$ & PR 126 & PR 126 & PR 121 & Pusa 44 & HKR 47 \\
\hline $\mathbf{2}$ & PR 121 & 55.5 & 44.5 & 0.0 & 0.0 \\
\hline $\mathbf{3}$ & Pusa 44 & 4.0 & 92.0 & 2.0 & 0.0 \\
\hline $\mathbf{4}$ & Pusa Basmati 1121 & 0.3 & 33.3 & 58.4 & 0.0 \\
\hline $\mathbf{5}$ & HKR 47 & 0.0 & 50.0 & 0.0 & 50.0 \\
\hline
\end{tabular}

\section{Yield}

Average yield in a particular time play an important role in adoption of variety. Consequently, PR 126 adopted by farmers on large scale in a 54 per cent area during kharif 2017.

\section{Land holding}

Farmers own small land holdings and most of them are cultivating crops by leasing in of the land. In order to make out payment of the land rent, average yield should be maximum in the shortest period of time.

Hence, the cropping intensity of the district is 196 per cent.

Owned land is a continuous variable used as a proxy to indicate a household's wealth. Feder et al., (1982) found that larger and wealthier farmers are more likely to adopt innovation and do so earlier than others. 


\section{Marketing of the produce}

Farmers prefer those varieties where there is no marketing problem and if there is any, the area under that variety is drastically reduced next year e.g., PAU 201, which was having a potential yield of $90 \mathrm{q} / \mathrm{ha}$ and farmers were harvesting up to $100 \mathrm{q} /$ ha but due to redness in the grain, the variety was totally neglected by the owners of the rice millers. As a result of which, the variety was withdrawn by the research institute despite of its highest yield.

\section{Farmer to farmer led extension}

It has been observed that farmer to farmer led extension plays a major role in the adoption of a technology to a large extent because farmers have more faith in the fellow farmers. However, the study of Ghimire et al., (2015) revealed that education, extension services and seed access play significant roles in adoption decisions. Additionally, farm and field characteristic variables such as farm size, endowment of favorable land type and animal power are the key factors influencing the probability of adopting new improved rice varieties.

Further, they showed that technology specific variables (e.g. yield potential and acceptability) are significant for explaining adoption behavior, implying that it is important to take farmers' preferences to varietal characteristics into consideration in the design of a research and development program.

\section{Seed Source}

Most of the time farmers are unaware about the seed source and get the seed purchased from their known dealers, however, it is very important to know about the class of seed, its purity percentage, germination etc., in order to harvest good yield.
Further, sometimes farmers store own produced crop and use it as seed in coming season without getting its germination percentage checked from the laboratory and may suffer a loss due to low or poor germination percentage leading to low yield. Under such situation, they always use about 10 to 20 per cent higher seed rate than the recommendations by the experts. This also results in increased cost of cultivation. Hence, While purchasing seed, farmers must obtain bill from the dealer or shopkeeper and the most important factor is that every time seed must be purchased from the reliable sources like research institutes or government agencies, as for as possible.

\section{Seed cost}

This is the most important factor affecting the adoption of a variety e.g., now a days there is a growing trend amongst the farmers to enquire about the subsidy being given by the state government on seeds and sometimes it is not available on newly released variety. This results in cultivation of that newly released variety on a smaller area. On the other hand, hybrid seeds from the private companies are very costly in comparison to the public sector seeds even then farmers opt those due to their marketing strategy and easy availability.

\section{Educational level}

Level of education increases farmers' ability to obtain, process, and use information relevant to adoption of improved technologies (Tadesse, 2008). Education is therefore expected to increase the probability of adoption of improved rice seed varieties in the study area.

The study on the adoption of paddy varieties in Kapurthala district revealed that many varieties have been released from time to time by the public and private research institutes 
but every year farmers prefer to grow a newly released variety. It was found that paddy variety PR 126 released by PAU Ludhiana during the year 2017, is a short duration variety and adopted by farmers on large scale in kharif 2017 because farmers are cultivating three crops in a year and thus, fits well in paddy-pea/potato-wheat crop rotation. Paddy is a main crop of kharif season and it has well established market in the district. In some areas of the district, PR 126 faced marketing problem because of its early harvesting time than the notified by the government. If this marketing problem is solved in the next year then it would be a prominent and wonderful paddy variety in coming years on the basis of per day productivity under crop intensification. Similarly, In paddy-wheat crop ration PR 121 and Pusa 44 were the first preference of farmers because of higher productivity and good net returns. Varietal characteristics, seed source and its cost, extension activities, package of practices of a variety and marketing are some of the important factors in adoption of a newly released variety in a particular area. Therefore, the significant role played by extension agencies, increased emphasis on information dissemination, field demonstration, and farmers' participatory research and training programs to popularize new rice varieties and enhance their adoption rate are required.

\section{References}

Abedullah S K and Mushtaq K (2007). Analysis of technical efficiency of rice production in Punjab (Pakistan). Pak Econ Soc Rev 45 (2):231-244.

Chandio A A, Magsi H, Rehman A and Sahito J G M (2017). Types, sources and importance of agricultural credits in Pakistan. J Appl Environ Biol Sci 7 (3):144-149.

Feder G, Just R E and Zilberman D (1982). Adoption of agricultural innovation in developing countries: A survey / Gershon Feder, Richard E. Just, David Zilberman. World Bank, Washington, D.C.

Ghimire R, Wen-chi H and shrestha R B (2015). Factors affecting adoption of improved rice varieties among rural farm households in central Nepal. Rice Sci 22 (1):35-43.

Singh Gobinder, Sandhu S S, Sharma Manoj and Singh Gurmeet (2015). Appraisal of varieties and fertilizer use in rice at farmers' field in district Kapurthala. $J$ Krishi Vigyan 3(2): 1-4.

Tadesse A M (2008). Farmers' evaluation and adoption of improved onion production package in Fogera District, south Gondar, Ethiopia. Dissertation for Award of MSc Degree at Haramaya University, Haramaya, Ethopia, 126pp.

\section{How to cite this article:}

Jatinder Manan, Manoj Sharma and Manpreet Jaidka. 2018. Factors Affecting the Adoption of Paddy Varieties in Kapurthala District of Punjab, India. Int.J.Curr.Microbiol.App.Sci. 7(09): 3014-3020. doi: https://doi.org/10.20546/ijcmas.2018.709.375 